\title{
Effects of fiscal
}

credibility on inflation

expectations: evidence

from an emerging

economy

\author{
JUAN CAMILO ANZOÁTEGUI-ZAPATA, MSc* \\ JUAN CAMILO GALVIS-CIRO, Ph.D.*
}

Article**

JEL: E37, E62, E61

https://doi.org/10.3326/pse.45.1.4

\footnotetext{
* The authors would like to thank two anonymous referees for helpful comments on earlier versions of this paper. Any remaining errors are the sole responsibility of the authors.

${ }^{* *}$ Received: July 16, 2020

Accepted: November 10, 2020
}

Juan Camilo ANZOÁTEGUI-ZAPATA

Universidad Autónoma Latinoamericana, Department of Economics, Carrera 55A No. 49-51, Medellín, Colombia e-mail: juan.anzoategui@unaula.edu.co

ORCiD: 0000-0003-0588-1364

Juan Camilo GALVIS-CIRO

Universidad Pontificia Bolivariana, Department of Economics, Circular 1 No. 70-01, Medellin, Colombia

e-mail: jcgalvisciro@gmail.com

ORCiD: 0000-0001-6680-275X 


\begin{abstract}
This paper analyses the impact of fiscal imbalances on expectations for an emerging economy with inflation targeting. In particular, based on the Colombian experience, we build a fiscal credibility index and evaluate its impact on inflation expectations for the 2004-2019 period. To analyse fiscal and monetary interactions, we propose an econometric model and use the OLS and GMM methods. The results show that the loss of fiscal credibility, associated with divergences between the fiscal deficit and agents' expectations, can increase inflation expectations by between $9 \%$ and $12 \%$. Furthermore, inflation expectations in Colombia incorporate important macroeconomic information related to unemployment, GDP and exchange rates.
\end{abstract}

Keywords: inflation expectations, fiscal policy, credibility

\title{
1 INTRODUCTION
}

The anchoring factors for inflation expectations are essential for fine-tuning an economic policy framework (Mankiw, Reis and Wolfers, 2003). In inflation targeting, expectations are monitored by central banks because agents set prices according to their inflation forecasting. These expectations affect the long-term structure of the interest rate, the planned expenditure and, therefore, inflation control (Blinder et al., 2008). According to the seminal contributions of Sargent and Wallace (1981), a fiscal policy stance is relevant for controlling inflation expectations. In this regard, if the public expects that the fiscal position is unsustainable, inflation expectations will not be low. Based on this relative consensus in economic theory, there is a growing and dynamic literature on the interactions between fiscal and monetary policies in emerging economies.

Prompted by Sargent and Wallace (1981), some studies have sought to analyse the empirical and theoretical relationship between fiscal variables and inflation expectations in economies with inflation targets. First, Catao and Terrones (2003) find that deficit/GDP ratio downturns produce a significant reduction in inflation, with more effects in countries with high and persistent inflation. A similar result is reported by de Mendonça and Machado (2013). Celasun, Gelos and Prati (2004) as well as de Mendonça and Tostes (2015) note that fiscal balance recoveries reduce inflation expectations and observed inflation. Other studies, such as Cerisola and Gelos (2009), suggest that the inflation target, past inflation, and the primary fiscal balance can anchor inflation expectations in emerging economies. Nonetheless, Celasun, Gelos and Prati (2004) provide empirical evidence that inflation expectations have backward-looking components despite inflation target announcements. Similar results are reported by Araujo and Gaglianone (2010) and Gaglianone (2017), who highlight that inflation expectations show persistence. Other perspectives, for example, Berlemann and Elzemann (2006), find that inflation expectations are driven by presidential election results and the probability that leftist parties will come to power. 
With central bank independence, the use of the inflation tax to achieve fiscal balance decreases (Minea and Tapsoba, 2014). Inflation targeting adoption leads to a government commitment to fiscal sustainability, which allows inflation expectations to be anchored in the central bank's targets (see, for example, Cerisola and Gelos, 2009). With this perspective being borne in mind, the objective of this paper is empirical and consists of examining the effects of fiscal credibility on inflation expectations in the Colombian economy.

Colombia is a small emerging economy in Latin America that has made important efforts to achieve better economic stability through a coherent and prudent policy. In the Colombian case, the government adopted the inflation targeting at the end of 1999. Since 2000, the Central Bank of Colombia has improved its communication with markets by informing them about inflation targets and monetary policy management (Hamann, Hofstetter and Urrutia, 2014). Since 2003, the central bank has implemented sophisticated methodologies to monitor inflation expectations, fiscal deficit expectations and expected economic growth. In the fiscal management strand, the government established a decreasing goal for the fiscal deficit to convince markets about fiscal balance sustainability. As a result, after more than 10 years, the Colombian economy recovered its investment grade (Moody's, 2014). In sum, Colombia is an interesting economic laboratory in which to analyse the interactions between monetary and fiscal policy (Ciro and de Mendonça, 2017).

This paper offers a new perspective on the problem of fiscal effects on inflation expectations. First, we use central bank expectations surveys and build a fiscal credibility index based on overall fiscal deficit expectations. Second, we analyse the long-term relationships that may exist between fiscal credibility and inflation expectations based on a cointegration model. Third, we verify whether, for the formation of inflation expectations, agents consider the available public information about macroeconomic variables. Finally, this study presents a contribution to the understanding of the effects of fiscal credibility on inflation expectations in the Colombian case. The results show that the loss of fiscal credibility, which is associated with divergences between the fiscal deficit and agents' expectations, can increase inflation expectations by between $9 \%$ and $12 \%$. Furthermore, this study shows that inflation expectations present inertia and react to GDP and the exchange rate. The evidence also indicates that the 2008 subprime crisis increased inflation expectations in Colombia.

The remainder of this paper is organized as follows: section 2 presents a literature review; section 3 presents the methodology for measuring fiscal credibility; section 4 provides empirical evidence, by means of econometric analysis, on the fiscal credibility effect on inflation expectations; and section 5 concludes the paper. 


\section{FISCAL CREDIBILITY AND INFLATION TARGETING}

The inflation targeting framework requires a high degree of coordination between the central bank and fiscal policy. In fact, for the policy framework to be credible, there cannot be permanent fiscal deficits that lead to fiscal dominance and public debt monetization (Mishkin and Savastano, 2001; Allsopp and Vines, 2005; De Mendonça, 2007). The absence of fiscal dominance is a requirement for inflation targeting (Mishkin and Savastano, 2001). For this, institutions are necessary to ensure the bank's independence and the government's commitments to fiscal balance (Wyplosz, 2005).

According to Gürkaynak, Levin and Swanson (2010), and Strohsal, Melnick and Nautz (2016), long-term inflation expectations should not respond to macroeconomic information when there is economic policy credibility. In Latin America, fiscal imbalances are a problem and cast doubt on monetary policy credibility. Fiscal balance is thus an indicator that must be carefully monitored to ensure the credibility of the inflation targets (Minea and Tapsoba, 2014). One strategy to resolve this problem resorts to the imposition of fiscal responsibility laws (Debrun, Hauner and Kumar, 2009; Lin and Ye, 2009; de Mendonça and da Silva, 2016). Following up on this idea, several studies have analysed the effect of fiscal targets or rules on inflation.

One strand of the literature has focused on measuring the effects of fiscal credibility in emerging economies under inflation targeting. This literature focuses on fiscal credibility indices to identify their effects on macroeconomic variables. In the case of Brazil, there are fiscal credibility indices on the deficit and public debt. The results of these studies show that fiscal credibility helps to anchor inflation expectations, reduces inflationary pressures and exchange rate pass-through on inflation, lowers disagreement in fiscal expectations and stabilizes market interest rates (de Mendonça and Tostes, 2015; de Mendonça and da Silva, 2016; Montes and Acar, 2018). According to de Mendonça and Machado (2013), an increase in fiscal credibility helps fixed rate bonds to be issued. Furthermore, credibility reduces the public debt indexed to market interest rates. Along this same line, the study by Montes and Souza (2020) suggests that greater fiscal credibility reduces sovereign risk.

Other studies have found similar results without using credibility indices. Thornton and Vasilakis (2019), using a sample of 61 low- and middle-income countries, find that countries that adopted transparent fiscal rules increased their fiscal credibility. Moreover, in the case of Indonesia, Kunkoro (2015) shows that rules for the fiscal deficit are a device to obtain fiscal credibility. Furthermore, credibility reduces deficit volatility and contributes to price stability. A similar result is reported for the case of Japan. According to Shirakawa (2012), when the government loses credibility regarding debt sustainability, inflation increases, boosting interest rates and increasing default probabilities. Similarly, for the case of the Czech Republic, Klyuev and Snudden (2011) demonstrate that public expectations about the government's commitments to fiscal consolidation can improve its 
credibility. According to their results, fiscal credibility helps higher tax incomes and lower market interest rates to be achieved.

Other empirical studies measure credibility through financial markets' reactions. In particular, Kandil and Morsy (2014) propose that fiscal credibility can be measured by the confidence that markets show in fiscal stimuli. According to their results, fiscal stimuli backed by international reserves generate greater credibility and increase the impact of stimuli related to public spending. In addition, credible market announcements help reduce the costs associated with loans and debt service.

\subsection{THE COLOMBIAN CASE}

The Bank of the Republic, the central bank of Colombia, emerged in 1923 as an issue, transfer, deposit, and discount bank and is the highest monetary, exchange and credit authority in Colombia. The bank functioned as a development bank for the economic growth of Colombia between 1930 and 1980. In those years, coffee growers, industrialists, merchants, and other agents had representation on the board of directors. In this period, the Colombian economy exhibited average annual inflation rates of $20 \%$.

The independence of the central bank was achieved in 1991 with the reform of the political constitution of Colombia. At that time, the reform created a board of directors for the bank, made up of seven members: the general manager, a representative of the government, who is the Minister of Finance and Public Credit, and five full-time members. As a positive sign of independence between monetary and fiscal policy, to date, the Board of Directors has never approved loans to the government to finance the fiscal deficit.

In 2000, the Central Bank of Colombia adopted an inflation targeting regime, and inflation rates have averaged 5\% per year. Inflation targeting was adopted as a monetary policy response to anchor inflation expectations and increase fiscal restrictions (Gómez, 2006; López-Enciso, Vargas-Herrera and Rodríguez-Niño, 2016). To support the central bank, since 2004, the Colombian government has had debt controls and a medium-term fiscal framework that provides information about fiscal plans. In addition, in 2012 the Colombian government adopted a fiscal rule to progressively reduce the fiscal deficit. The objective of this rule is to achieve a primary fiscal deficit of less than 1\% of GDP from 2022 (López-Enciso, Vargas-Herrera and Rodríguez-Niño, 2016). To achieve these targets, the government has carried out tax reforms to reduce the fiscal deficit. Despite all these fiscal commitments, reforms have been partial, with an average of one tax reform every two years. As a result, fiscal imbalances have not been resolved and fiscal credibility is low.

\section{METHODOLOGY}

Fiscal policy has effects on macroeconomic stability and must be managed in a liable and coherent manner (Fatás and Mihov, 2003). Fiscal credibility is an asset for governments and indicates that agents believe that fiscal targets will be achieved and that a sustainable fiscal position will be maintained (Hauner, Jonáš 
and Kumar, 2007). In particular, fiscal credibility is relevant to policymakers because it can help guide the market in a way that avoids rising inflation expectations (de Mendonça and Machado, 2013).

It is important to note that, in the case of emerging economies, fiscal deficits constantly put the fulfilment of the central bank's objectives at risk. As a result, inflation expectation control is affected by fiscal credibility (Cerisola and Geros, 2009). This paper evaluates the effects of fiscal credibility on inflation expectations for the case of the Colombian economy based on central bank expectations surveys. These surveys average 40 participants among private banks, stockbrokers, pension funds, academics and international organizations. In the present study, inflation expectations are calculated as 1-year-ahead inflation forecasts of the participants surveyed. This information is available to the public through its central bank time series statistics system. Drawing on the information available, we present the inflation expectations for the 2004-2019 period in figure 1 .

\section{Figure 1}

Inflation expectations in the Colombian economy (in \%)

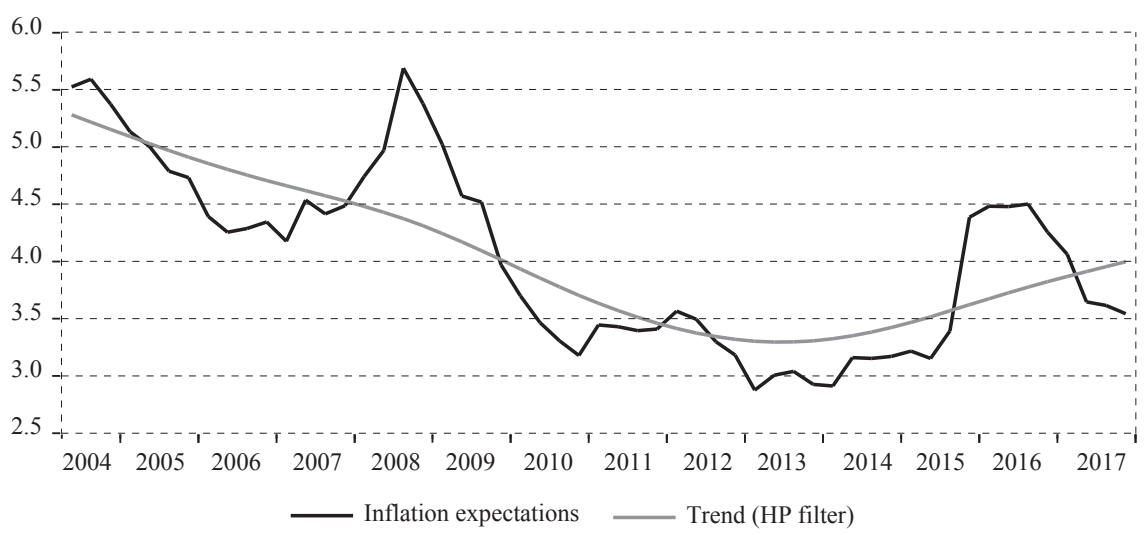

Source: Author's elaboration. Data from the Central Bank of Colombia. Trend calculated with the Hodrick-Prescott filter.

Inflation expectations declined between 2004 and 2013 towards the central bank's long-term inflation target, which was set at 3\%. This process was partially interrupted by the subprime crisis of 2007-2008. Since 2014, there has been an increase in inflation expectations due to the great difficulty of controlling some unexpected events, such as a strong devaluation in the exchange rate and some internal crises caused by internal political problems related to monetary policy.

There are several challenges in measuring fiscal credibility because the government's budget constraint involves several variables. According to de Mendonça and Machado (2013), fiscal credibility can be evaluated by public confidence in relation to the government's ability to avoid the risk of default. Moreover, it is possible to affirm that there is fiscal credibility when there is a government 
commitment to the sustainability of public finances. As a result, there is credibility when the government does not use the inflation tax to fulfil its obligations (Hauner, Jonas and Kumar, 2007; Debrun and Kinda, 2017).

To make credibility measurable, there are several proposals. According to Drazen and Masson (1994), credibility can be measured by agents' expectations regarding the fiscal results. Another approach is offered by Naert (2011), who postulates that fiscal policy is credible if there is little difference between the current level and the projected level of some fiscal measure. The challenge is to define some measure of fiscal performance on which agents form expectations and make projections. Based on Debrun and Kinda (2017), fiscal performance can be measured by the overall fiscal deficit, that is, by the difference between expenditures, debt service and taxes. Hence,

$$
D E F_{t}=G_{t}+r D_{t-1}-T_{t}
$$

where $D E F_{t}$ is the overall fiscal deficit, $G_{t}$ is the public expenditure, $r D_{t-1}$ is the public debt interest, and $T_{t}$ is the tax revenues. All the variables are defined as a percentage of the gross domestic product (GDP).

An essential point regarding the credibility of economic policy is public expectation. According to Cukierman and Meltzer (1986), credibility can be measured as the absolute value of the difference between the policymaker's plans and the public's beliefs about those plans. Moreover, as highlighted by Faust and Svensson (2001), credibility is negatively related to the distance between agents' expectations and the achievements of the policy maker. Following Hauner, Jonas and Kumar (2007), fiscal credibility can be approximated by the difference between agents' expectations of the fiscal deficit $\left(E\left(D E F_{t}\right)\right)$ and the fiscal deficit achieved by the government $\left(D E F_{t}\right)$. In other words, the greater the difference between the observed fiscal deficit and agents' expectations, the less fiscal credibility there is because there is no convergence in agents' beliefs.

From that perspective, this paper uses a credibility loss indicator (CRED_LOSS) that considers the differences between the agents' expectations about the fiscal deficit and the overall fiscal deficit observed (as an absolute value):

$$
C R E D \_L O S S_{t}=\left|E\left(D E F_{t}\right)-D E F_{t}\right|
$$

where $E(D E F)$ is agents' expectations about the overall fiscal deficit and $D E F$ is the overall fiscal deficit observed. The behaviour of both variables over time is presented in figure 2. The agents' expectations regarding the overall fiscal deficit are extracted from the survey of the Central Bank of Colombia called "Macroeconomic Projections of Local and Foreign Analysts". In this survey, the central bank asks brokers, commercial banks, pension funds, academic institutes, and rating agencies about the quarterly forecast of several macroeconomic variables, 
including the overall fiscal deficit. The quarterly data are available from 2004 (see appendix, table A1).

The behaviour of both variables $(D E F$ and $E(D E F))$ over time is presented in figure 2 below. It is observed that from 2004 to 2008, expectations underestimated the observed fiscal deficit. Then, since the end of 2008, expectations began to grow and were located close to the fiscal deficit, surpassing it in 2010. Between 2010 and 2011, the government adopted a fiscal rule on the primary fiscal deficit, and from then on, expectations began to fall. From 2012 to 2016, there has been an increase in the observed fiscal deficit and, consequently, in expectations. This increase in variables peaked in 2016. Since then, there has been a drop in both the observed deficit and the expectations.

\section{Figure 2}

Fiscal deficit expectations and overall fiscal deficit observed in Colombia (in \% of GDP)

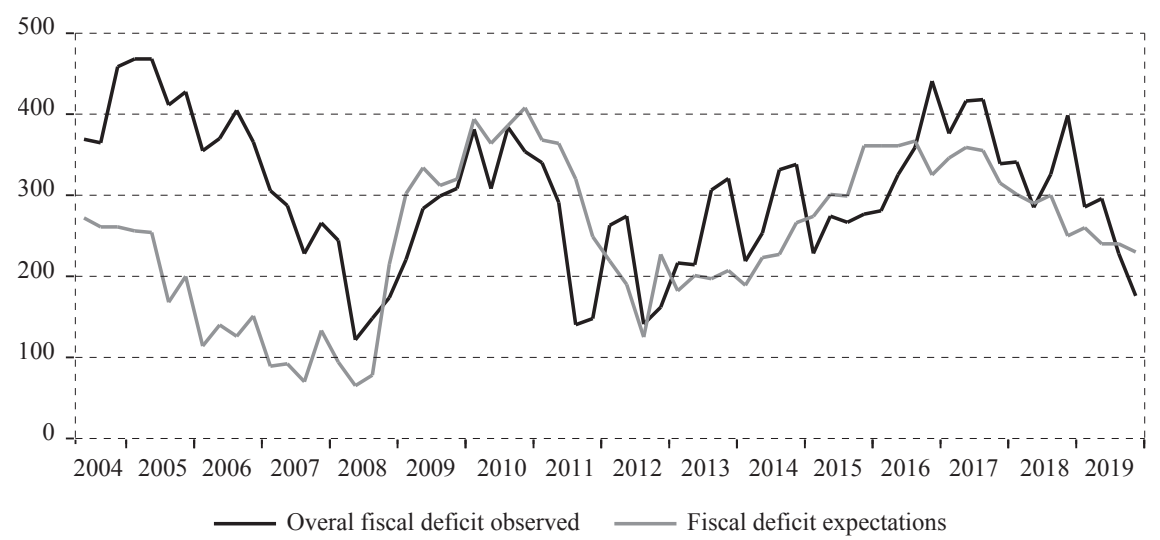

Source: Author's elaboration. Data from the Central Bank of Colombia.

Figure 3 shows the performance of fiscal credibility loss (CRED LOSS) from 2004 to 2019 in Colombia. The CRED LOSS indicator shows that there was uncertainty about fiscal policy in the 2006-2008 period. As a result, fiscal credibility loss was high in that period. Once expectations began to approach the observed deficit, the loss of credibility eased and reached a low of $0.14 \%$ in 2011Q1. After this, we began to observe an unstable behaviour of credibility loss. Despite this, the trend of the series shows that the loss of credibility was stable between 2012 and 2019. For the full period (2004-2019), the credibility loss was $0.9 \%$ on average.

Since the seminal contribution of Kydland and Prescott (1977), economic theory has assumed that an agent's expectations depend on the government's credible commitment to an announced target. In other words, the expected path of the fiscal deficit matters for the formation of inflation expectations. In particular, when there is no commitment to fiscal equilibrium, government liabilities are ensured with seigniorage and the outcome is an increase in expected inflation (Sargent and Wallace, 1981). 


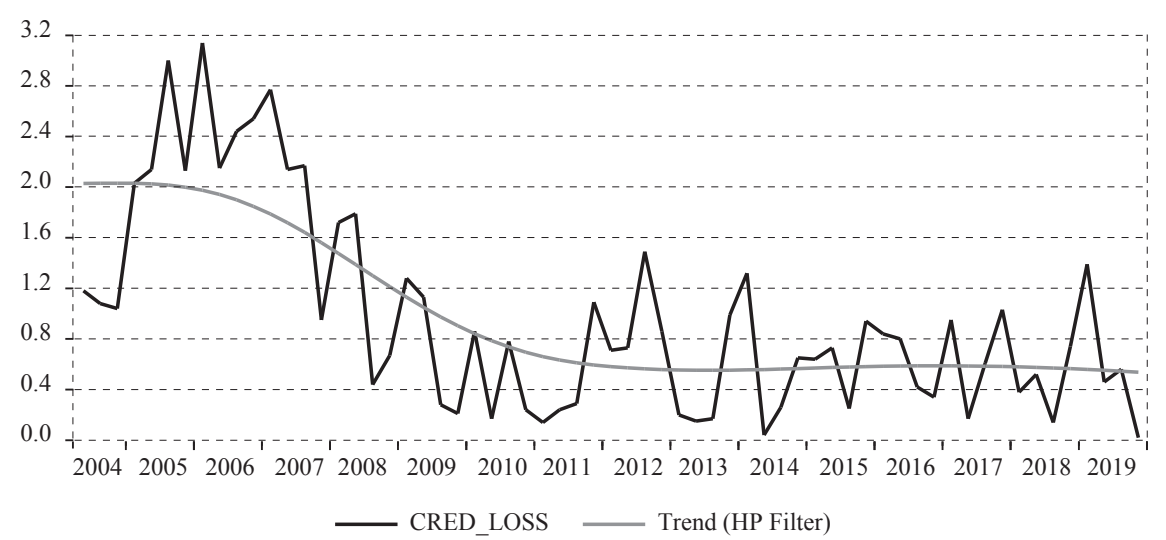

Source: Author's elaboration. Data from the Central Bank of Colombia.

Credibility is the ability of policymakers to inspire confidence, and it can help form expectations. According to Mishkin (2007), inflation targeting in an environment of low fiscal credibility causes difficulties in managing inflation expectations and impacts the effectiveness of monetary policy. Hence, the baseline model considered in our empirical analysis is as follows:

$$
E\left(\pi_{t}\right)=\beta_{1}+\beta_{2} C R E D \_L O S S_{t}+\alpha_{3} X_{t}+\varepsilon_{t}
$$

where $E\left(\pi_{t}\right)$ is the annualized inflation expectations, CRED_LOSS is the fiscal policy credibility loss, $X_{t}$ is a vector of explanatory variables, and $\varepsilon_{t}$ is the residual term.

To observe an initial empirical relationship between inflation expectations and fiscal credibility loss, a scatter plot for both variables is presented in figure 4 . The theoretical intuition of a positive relationship between both variables is confirmed. Thus, a better projection of the fiscal deficit can lead to a reduction in inflation expectations.

It is important to verify whether the public information available on macroeconomic and financial variables is taken into consideration by the agents. For this, it is useful to use the most recent data for inflation forecasts (Mankiw, Reis and Wolfers, 2003). Financial market volatility affects the performance of emerging economies and, indirectly, the formation of expectations (Kennedy and Palerm, 2014). For the Colombian case, the international economy outlook causes volatility in capital flows and the balance of payments that can impact inflation expectations. Therefore, we use behaviour of the S\&P 500 stock market index $\left(V I X_{t-1}\right)$ as our first explanatory variable for inflation expectations. 


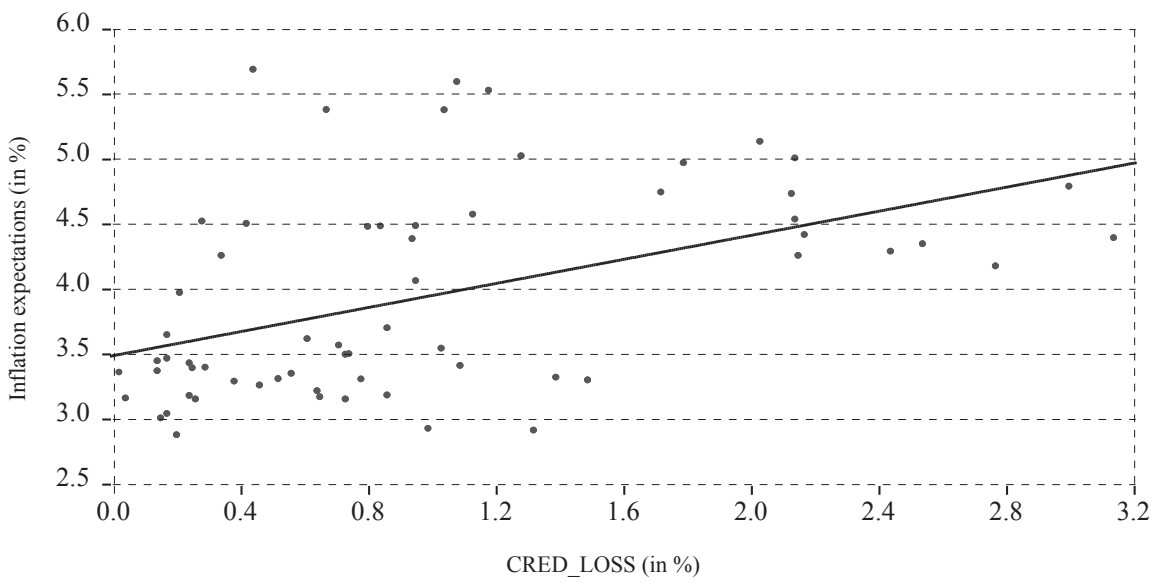

Source: Author's elaboration. Data from the Central Bank of Colombia.

Expectations depend on past information, and each agent interprets the available information in a different way (Roberts, 1997). In fact, the increase in inflation expectations can be attributed to backward-looking behaviour (Dornbusch and Fischer, 1993). Therefore, past inflation $\left(\pi_{t-1}\right)$ is used as the second explanatory variable.

In emerging economies, movements in the exchange rate impact marginal costs and inflation forecasts (Celasun, Gelos and Prati, 2004). In particular, the Colombian economy has an important pass-through of the exchange rate to domestic inflation through its cost effects. Thus, as the third explanatory variable, the past exchange rate $\left(e_{t-1}\right)$ is used.

According to the Neo-Keynesian Phillips Curve model, inflation expectations are related to the profit mark-up over costs. These mark-up changes are a function of the economic cycle (Woodford, 2003). Thus, we use GDP $\left(y_{t-1}\right)$ as the fourth explanatory variable for inflation expectations.

On the basis of Okun's law, it is possible to establish a relationship between output and the labour market. Accordingly, as an alternative measure of the economy, the past unemployment rate, is used as the fifth explanatory variable for inflation expectations $\left(U_{t-1}\right)$.

In short, to analyse the effect of fiscal credibility on inflation expectations we used an explanatory variable associated with external risk $\left(V I X_{\mathrm{t}-1}\right)$, two measures associated with past prices $\left(\pi_{t-1}, e_{t-1}\right)$ and two measures associated with economic performance $\left(y_{t-1}, U_{t-1}\right)$. The past inflation expectations are also incorporated as an explanatory variable $\left(E\left(\pi_{t-1}\right)\right)$ to capture some inertia in expectations. A dummy variable $\left(D_{t}\right)$ is also added to capture the possible effect of the 2007-2008 
subprime crisis. This dummy takes a value of 1 for the year 2008. ${ }^{1}$ Thus, the possible combinations of these variables allow us to postulate the following models:

$$
\begin{aligned}
& E\left(\pi_{t}\right)=\alpha_{0}+\alpha_{1} E\left(\pi_{t-1}\right)+\alpha_{2} \text { CRED_LOSS }+\alpha_{3} V I X_{t-1}+\alpha_{4} \pi_{t-1}+\alpha_{5} y_{t-1}+\alpha_{6} D_{t}+\varepsilon_{t}^{0} \\
& E\left(\pi_{t}\right)=\alpha_{7}+\alpha_{8} E\left(\pi_{t-1}\right)+\alpha_{9} \text { CRED_LOSS }+\alpha_{10} V I X_{t-1}+\alpha_{11} e_{t-1}+\alpha_{12} y_{t-1}+\alpha_{13} D_{t}+\varepsilon_{t}{ }^{1} \\
& E\left(\pi_{t}\right)=\alpha_{14}+\alpha_{15} E\left(\pi_{t-1}\right)+\alpha_{16} \text { CRED_LOSS } S_{t}+\alpha_{17} V I X_{t-1}+\alpha_{18} \pi_{t-1}+\alpha_{19} U_{t-1}+\alpha_{20} D_{t}+\varepsilon_{t}^{2} \\
& E\left(\pi_{t}\right)=\alpha_{21}+\alpha_{22} E\left(\pi_{t-1}\right)+\alpha_{23} \text { CRED_LOSS }+\alpha_{24} V I X_{t-1}+\alpha_{25} e_{t-1}+\alpha_{26} U_{t-1}+\alpha_{27} D_{t}+\varepsilon_{t}^{3}
\end{aligned}
$$

Additionally, we estimate the full model with all the variables:

$$
\begin{aligned}
E\left(\pi_{t}\right)= & \alpha_{28}+\alpha_{29} E\left(\pi_{t-1}\right)+\alpha_{30} \text { CRED_LOSS }_{t}+\alpha_{31} V I X_{t-1}+\alpha_{32} \pi_{t-1}+\alpha_{33} y_{t-1} \\
& +\alpha_{34} e_{t-1}+\alpha_{35} U_{t-1}+\alpha_{36} D_{t}+\varepsilon_{t}^{4}
\end{aligned}
$$

The period under consideration is from 2004-1 to 2019-4 (quarterly data). The choice of the period is due to data availability for the fiscal deficit expected, which are necessary to build the credibility index. See table A1 (appendix) for the sources of data and descriptions of all variables used in the study.

\section{EMPIRICAL EVIDENCE}

As in previous literature, the use of time series data in estimations entails verifying whether unit roots exist. Therefore, before carrying out the estimations of all models, the increased Dickey-Fuller unit root test (ADF), the Phillips-Perron test (PP) and the Kwiatkowski-Phillips-Schmidt-Shin (KPSS) stationarity test were performed. The results are presented in table A3 (appendix). Based on the results of the tests, the variables to be used in equations (4)-(8) are $I(1)$ and have the same order of integration.

According to Engle and Granger (1981), it is possible to estimate the models proposed if there is a stationary combination in the series. Cointegration tests were performed for the proposed model. The choice of VAR lag and the inclusion of the deterministic components of the cointegration vector was made on the basis of the Schwarz criterion (Harris, 1995). The cointegration test proposed by Johansen (1991) based on the significance of the estimated eigenvalues indicates the existence of a cointegration vector in the models (see table A3, appendix). Thus, the models were estimated with the series in levels without problems of spurious regressions.

\footnotetext{
${ }^{1}$ Beside the presented models, we also estimated models with output gap replacing GDP as well as by including more lags of inflation. The obtained results were not statistically significant and are available upon request.
} 
136

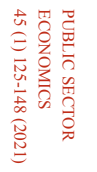

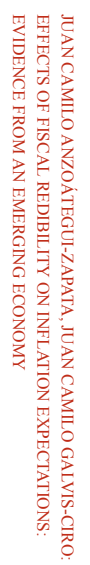

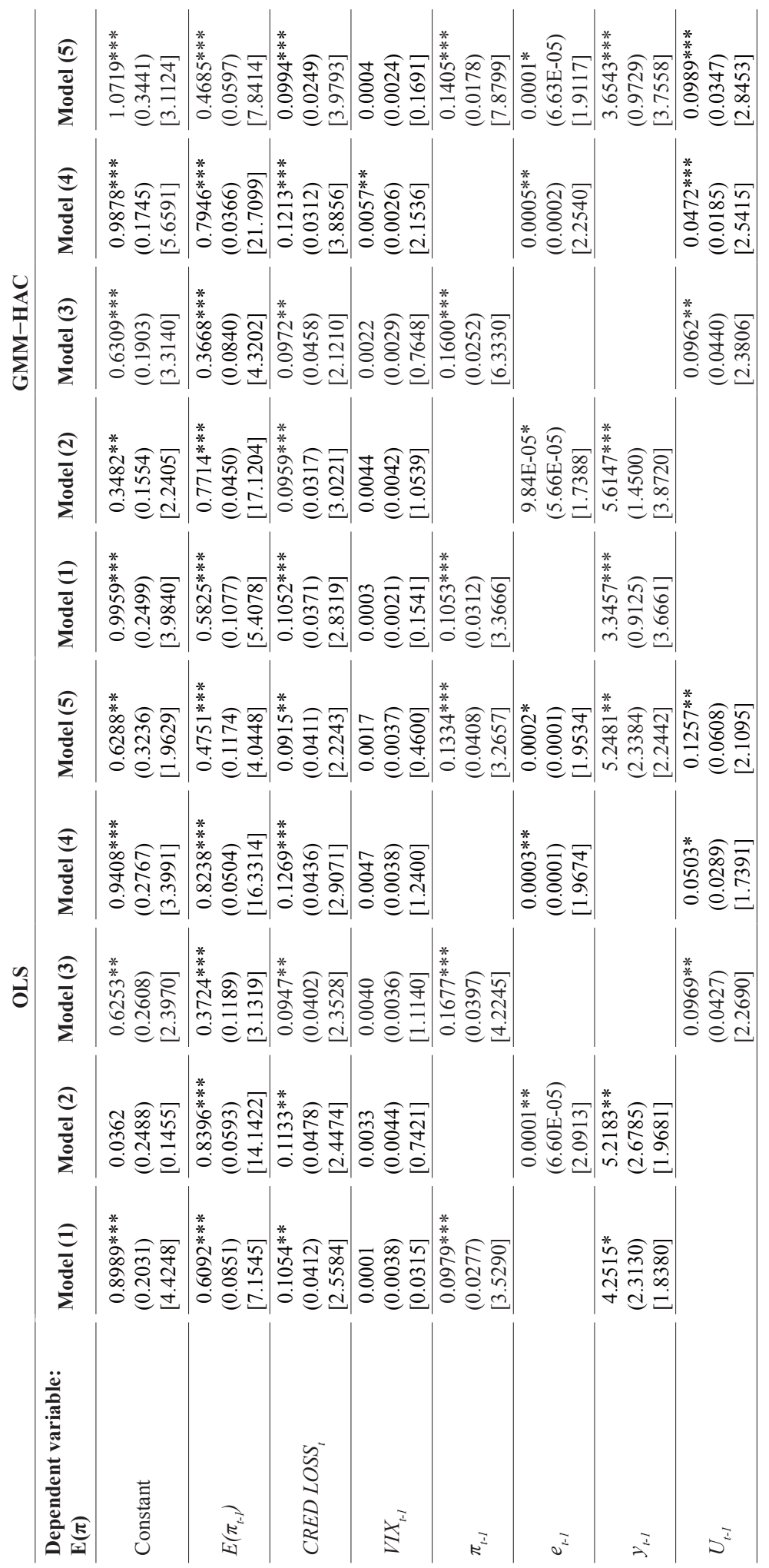



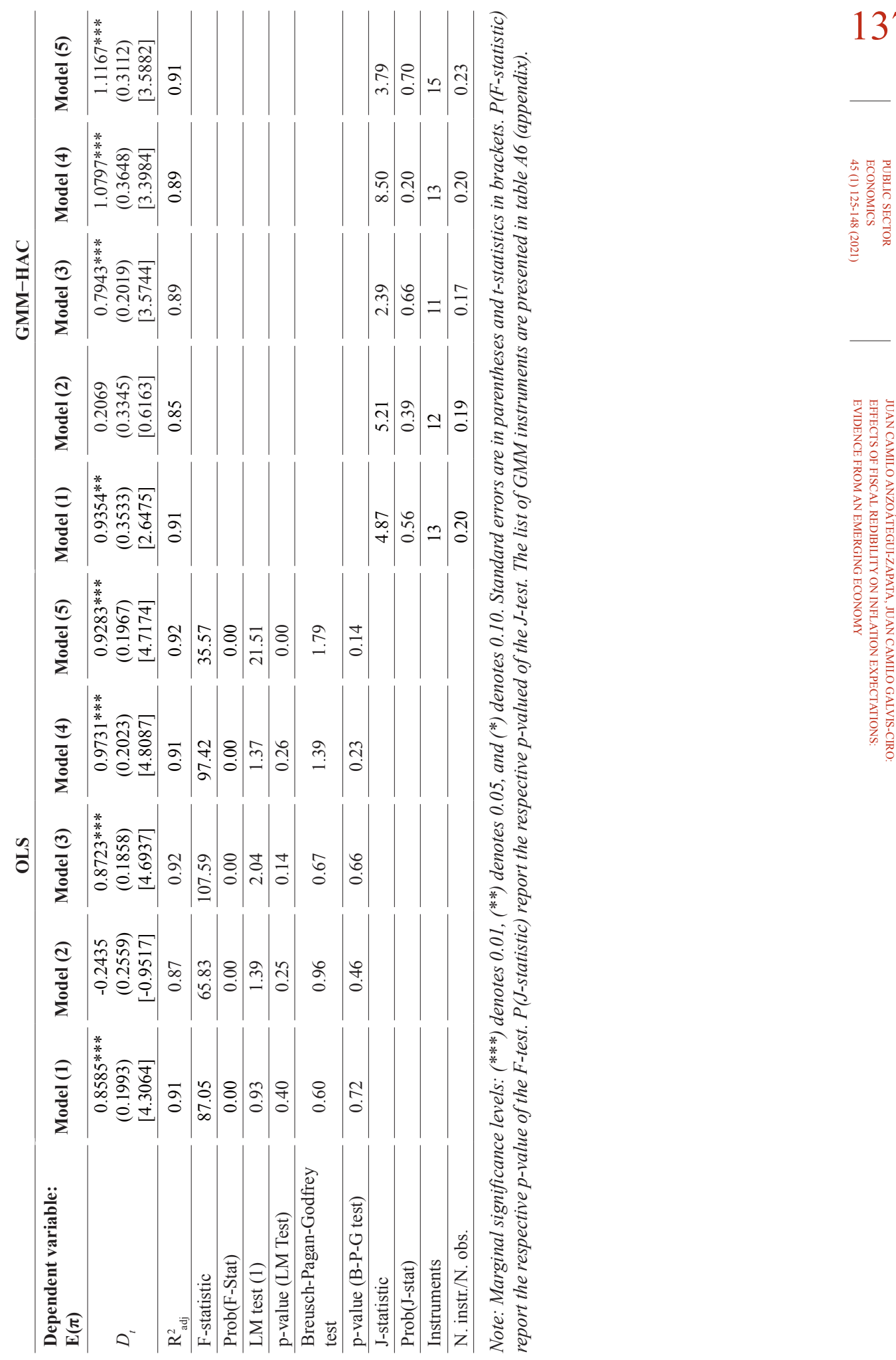
The equations above were estimated using Ordinary Least Squares (OLS) and Generalized Method of Moments (GMM). In the case of the models estimated with OLS, tests of autocorrelation (LM test) and heteroscedasticity (BreuchPagan-Godfrey test) were applied to validate the estimates. According to Hansen (1982), the main reason for using the GMM method is because endogeneity and autocorrelation problems may exist, which will invalidate the OLS estimates. Given this, in GMM estimates the instruments chosen were lagged for at least one period. According to Wooldridge (2001), to obtain efficient estimations with the GMM method, overidentification restrictions are necessary. In this sense, the J test was applied. The estimations of equations (4)-(8) are presented in table 1.

The results of the estimates show the expected sign. The parameter associated with past expectations $\left(E\left(\pi_{t-1}\right)\right)$ is positive and significant. Inflation expectations present some inertia with the expectations of the past period. That is, there is some evidence that expectations are adaptive, and agents learn slowly. A similar result is reported by Mankiw, Reis and Wolfers (2003).

The coefficient associated with fiscal credibility loss (CRED LOSS) is positive and statistically significant in all models. The theoretical intuition that the fiscal policy stance has been important in shaping inflation expectations is confirmed. Thus, when confidence grows about the government's commitment to fiscal sustainability, the expected inflation decreases. The evidence supports the theoretical perspective of Sargent and Wallace (1981) and the findings confirm that the lower uncertainty about the expected fiscal deficit and, therefore, greater fiscal credibility matter for inflation expectations. Similar results are reported by Kuncoro (2015), Cerisola and Geros (2009), and Celasun, Gelos and Prati (2004).

With the results in table 1, we calculated that an increase of one unit in CRED LOSS can boost inflation expectations in a range that varies between $9.15 \%$ and $12 \%$. For example, if inflation expectations are at $3 \%$, an increase of one unit in CRED LOSS can increase expectations to a range between $3.27 \%$ and $3.36 \% .^{2}$ Therefore, according to Celasun, Gelos and Prati (2004), the findings show that building fiscal credibility is relevant to anchoring inflation expectations.

On the other hand, in relation to the coefficient associated with past external risk $\left(V I X_{t-1}\right)$, the estimations show that the parameter is not significant. This finding suggests that increases in global financial uncertainty do not increase inflation expectations in Colombia. The importance of past inflation $\left(\pi_{t-1}\right)$ for the formation of expectations is also significant. Using the results of Bomfim and Rudebusch (2000), it is possible to affirm that since inflation expectations respond to past inflation, monetary policy in Colombia is not fully credible. According to the results, the coefficient associated with past inflation varies between $9.79 \%$ and

${ }^{2}$ CRED LOSS is calculated in the units in which the fiscal deficit is measured as percentage of GDP. Therefore, an increase of one unit in CRED LOSS means that deficit expectations are $1 \%$ (\% of GDP) above the observed deficit. 
$16.77 \%$. Therefore, if past inflation increases one unit and expectations are at $3 \%$, the result is that expectations can move to between $3.29 \%$ and $3.50 \%$. However, this result suggests that inflationary inertia has fallen in Colombia and expectations are better anchored. Some empirical studies highlight similar results for emerging economies that have adopted inflation targeting (see, Celasun, Gelos and Prati, 2004; Bevilaqua, Mesquita and Minella, 2008; Cerisola and Geros, 2009; Gaglianone, 2017).

In the case of the parameter associated with the exchange rate $\left(e_{t-1}\right)$, the coefficient is positive and significant. Accordingly, depreciation tends to increase inflation expectations in the Colombian economy. This result indirectly confirms the hypothesis that firm costs are tied to the behaviour of the exchange rate due to its effects on imported inputs. However, in the estimated models, the estimated parameter tends toward zero, which indicates that very high devaluations (above 1,000 Colombian pesos) are necessary for expectations to increase by more than one percentage point. Similar evidence has been reported by Bevilaqua, Mesquita and Minella (2008), Araujo and Gaglianone (2010), and Gaglianone (2017).

The coefficient associated with the past behaviour of the economy $\left(y_{t-1}\right)$ is positive and statistically significant. That is, inflation expectations fall in recessions and rise in economic booms. In the case of the coefficient associated with the past unemployment rate $\left(U_{t-1}\right)$, the econometric result shows that it is also positive and significant. According to Mankiw, Reis and Wolfers (2003), inflation expectations are high during periods of high unemployment, suggesting a belated overreaction of expectations to the labour market situation. With the results of table 1 , an increase in the past unemployment rate leads to increases in inflation expectations in a range between 0.04 and 0.12 percentage points. The results confirm the theoretical perspective of the Kydland and Prescott (1977) dynamic incoherence models. These models indicate that increases in unemployment can be the result of attempts to surprise agents with unexpected inflation. Expansive policy can lead to short-term gains in terms of product increases, as the Phillips curve points out. However, according to the findings of Ireland (1999), in the long term, the result is a balance in which the inertia of inflation expectations is positively cointegrated with the unemployment rate. Thus, the evidence suggests that during the period of analysis, there was no trade-off between inflation expectations, inflation and unemployment. Finally, the coefficient associated with the dummy variable $\left(D_{t}\right)$ is positive and significant in almost all models. In other words, the subprime crisis raised inflation expectations in Colombia.

\subsection{OLS RECURSIVE ESTIMATES}

It is important to verify the way in which the effect of fiscal credibility on inflation expectations has varied over time. For this, OLS recursive estimates were performed on the coefficient of fiscal credibility loss (CRED LOSS) estimated in the five models presented in table 1 . The stability over time of the parameters associated with fiscal credibility is presented in figure 5 . 
In general, the estimates show that for the period analysed, the signs and effects of fiscal credibility on inflation expectations were stable, but in 4 of the 5 models, the parameters decreased. According to the graphs, the parameters associated with the CRED LOSS variable dropped from $20 \%$ to $10 \%$. Thus, the impact of credibility was reduced by a half. In the 2016-2019 period, the effect of credibility stabilized, and the results confirm the importance of fiscal policy in the shaping of inflation expectations in Colombia.

\section{Figure 5}

Fiscal credibility coefficient: recursive estimates, model 1, 2, 3, 4, 5 (in \%)
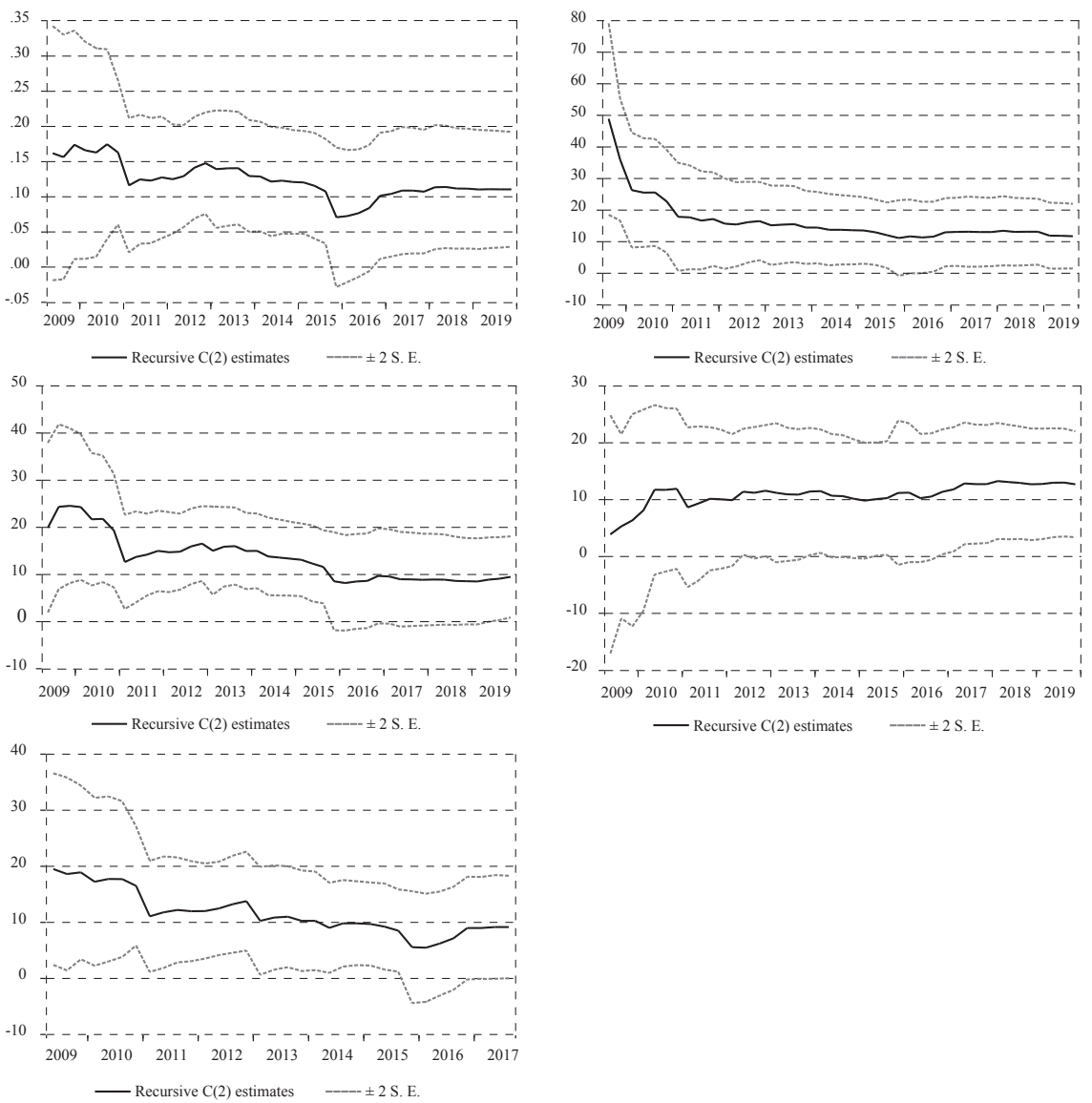

- Recursive C(2) estimates ----- \pm 2 S. E.

Source: Author's elaboration. Data from the Central Bank of Colombia.

\section{CONCLUSIONS}

This study analysed the influence of fiscal credibility on inflation expectations in the Colombian economy. The results allow us to make three observations. First, econometric estimate results indicate that an anchoring of expectations in the observed fiscal deficit (lower CRED LOSS) can reduce inflation expectations. In particular, the findings show that fiscal credibility should be monitored by the central bank in 
its efforts to stabilize expectations. Second, past inflation behaviour continues to be important in determining inflation expectations. Thus, the results suggest that there is still a gap in strengthening the management of expectations in long-term central bank targets and incorporating forward-looking behaviour. Third, inflation expectations in Colombia incorporate important macroeconomic information related to unemployment, GDP and exchange rates. In brief, the empirical evidence developed in this study indicates that to stabilize inflation expectations in Colombia, it is necessary to have a stable economic environment and credible fiscal policy.

\section{Disclosure statement}

No potential conflict of interest was reported by the authors. 
1. Allsopp, C. and Vines, D., 2005. The macroeconomic role of fiscal policy. Oxford Review of Economic Policy, 21(4), pp. 485-508. https://doi.org/10.1093/ oxrep/gri027

2. Araujo, C. and Gaglianone, W., 2010. Survey-based Inflation Expectations in Brazil. BIS Papers, 49, pp. 107-114.

3. Berlemann, M. and Elzemann, J., 2006. Are expectations on inflation and election outcomes connected? An empirical analysis. Economic Letters, 91(3), pp. 354-359. https://doi.org/10.1016/j.econlet.2005.12.007

4. Bevilaqua, A., Mesquita, M. and Minella, A., 2008. Brazil: Taming Inflation Expectations. Working Papers Central Bank of Brazil, (129), pp. 1-40.

5. Blinder, A. [et al.], 2008. Central Bank Communication and Monetary Policy. Journal of Economic Literature, 46(4), pp. 910-945. https://doi:10.1257/ jel.46.4.910

6. Bomfim, A. and Rudebusch, G., 2000. Opportunistic and Deliberate Disinflation Under Imperfect Credibility. Journal of Money, Credit and Banking, 32(4), pp. 707-721. https://doi.org/10.2307/2601179

7. Catao, L. A. and Terrones, M., 2003. Fiscal Deficits and Inflation. IMF Working Paper, No. 03/65. Washington: International Monetary Fund. https://doi. org/10.5089/9781451848700.001

8. Celasun, O. and Gelos, G., 2009. What drives inflation expectations in Brazil? An empirical analysis. Applied Economics, 41(10), pp. 1215-1227. https://doi. org/10.1080/00036840601166892

9. Celasun, O., Gelos, G. and Prati, A., 2004. Obstacles to disinflation: what is the role of fiscal expectations? Economic Policy, 19, pp. 441-81. https://doi. org/10.1111/j.1468-0327.2004.00129.x

10. Cerisola, M. and Gelos, G., 2009. What Drives Inflation Expectations in Brazil? An Empirical Analysis. Applied Economics, 41(10), 1215-1227. https:// doi.org/10.1080/00036840601166892

11. Ciro, J. C. G . and De Mendonça, H. F., 2017. Effect of credibility and reputation on discretionary fiscal policy: empirical evidence from Colombia. Empirical Economics, 53(4), pp. 1529-1552. https://doi.org/10.1007/s00181-016-1177-2

12. Cukierman, A. and Meltzer, A. H., 1986. A theory of ambiguity, credibility, and inflation under discretion and asymmetric information. Econometrica, 54(5), pp. 1099-1128. https://doi: 10.2307/1912324

13. De Mendonça, H. F., 2007. Towards credibility from Inflation targeting: the Brazilian experience. Applied Economics, 39(20), 2599-2615. https://doi. org/10.1080/00036840600707324

14. De Mendonça, H. F. and Da Silva, R., 2016. Observing the influence of fiscal credibility on inflation: Evidence from an emerging economy. Economics Bulletin, 36 (4), pp. 2333-2349.

15. De Mendonça, H. F. and Machado, M. R., 2013. Public Debt Management and Credibility: Evidence from an emerging economy. Economic Modelling, 30(1), pp. 10-21. https://doi.org/10.1016/j.econmod.2012.09.009 
16. De Mendonça, H. F. and Tostes, F. S., 2015. The effect of monetary and fiscal credibility on exchange rate pass-through in an emerging economy. Open Economies Review, 26(4), 787-816. https://doi.org/10.1007/s11079-014-9339-3

17. Debrun, X., Hauner, D. and Kumar, M., 2009. Independent Fiscal Agencies. Journal of Economic Surveys, 23(1), pp. 44-81. https://doi.org/10.1111/j.14676419.2008.00556.x

18. Debrun, X. and Kinda, T., 2017. Strengthening Post-Crisis Fiscal Credibility: Fiscal Councils on the Rise - A New Dataset. Fiscal Studies, 38(4), pp. 667700. https://doi.org/10.1111/1475-5890.12130

19. Dornbusch, R. and Fischer, S., 1993. Moderate Inflation. World Bank Economic Review, 7(1), pp. 1-44. https://doi.org/10.1093/wber/7.1.1

20. Drazen, A. and Masson, P. R., 1994. Credibility of policies versus credibility of policymakers. Quarterly Journal of Economics, 109(3), pp. 735-754. https://doi: 10.2307/2118420

21. Engle, R. F. and Granger, C. W. J., 1987. Cointegration and error correction: Representation, estimation and testing. Econometrica, 55(2), pp. 251-276. https://doi: 10.2307/1913236

22. Fatás, A. and Mihov, I., 2003. The Case for Restricting Fiscal Policy Discretion. Quarterly Journal of Economics, 118(4), pp. 1419-1447. https://doi: $10.1162 / 003355303322552838$

23. Faust, J. and Svensson, L., 2001. Transparency and credibility: monetary policy with unobservable goals. International Economic Review, 42(2), pp. 369397. https://doi.org/10.1111/1468-2354.00114

24. Gaglianone, W., 2017. Empirical Findings on Inflation Expectations in Brazil: a survey. Working Papers Central Bank of Brazil, No. 464, pp. 1-25.

25. Gómez, J., 2006. La Política Monetaria en Colombia. Borradores de Economía, No. 394.

26. Gürkaynak, R., Levin, A. and Swanson, E., 2010. Does Inflation Targeting Anchor Long-Run Inflation Expectations? Evidence from the U.S., UK, and Sweden. Journal of the European Economic Association, 8(6), pp. 1208-1242. https://doi.org/10.1111/j.1542-4774.2010.tb00553.x

27. Hamann, F., Hofstetter, M. and Urrutia, M., 2014. Inflation Targeting in Colombia, 2002-2012. Borradores de Economía, 818, pp. 1-44. https://doi. org/10.32468/be. 818

28. Hansen, P. L., 1982. Large Sample Properties of Generalized Method of Moments Estimators. Econometrica, 50(4), pp. 1029-1054. https://doi: 10.23 $07 / 1912775$

29. Harris, R., 1995. Using cointegration analysis in econometric modeling. London: Prentice Hall.

30. Hauner, D., Jonáš, J. and Kumar, M., 2007. Policy Credibility and Sovereign Credit: The Case of the new EU Member States. IMF Working Paper, No. 07/1. Washington: International Monetary Fund. https://doi.org/10.5089/9781451865653.001

31. Ireland, P. N., 1999. Does the time-consistency problem explain the behavior of inflation in the United States? Journal of Monetary Economics, 44(2), pp. 279-91. https://doi.org/10.1016/S0304-3932(99)00026-4 
32. Johansen, S., 1991. Estimation and hypothesis testing of cointegration vectors in gaussian vector autoregressive models. Econometrica, 59(6), pp. 15511580. https://doi: 10.2307/2938278

33. Kandil, M. and Morsy, H., 2014. Fiscal Stimulus and Credibility in Emerging Countries. Eastern Economic Journal, 40, pp. 420-439. https://doi.org/10.1057/ eej.2013.25

34. Kennedy, M. and Palerm, A., 2014. Emerging market bond spreads: The role of global and domestic factors from 2002 to 2011. Journal of International Money and Finance, 43(1), pp. 70-87. https://doi.org/10.1016/j.jimonfin.2013.12.008

35. Klyuev, V. and Snudden, S., 2011. Effects of fiscal consolidation in the Czech Republic. Czech Journal of Economics and Finance, 61(4), pp. 306-326. https://doi.org/10.5089/9781455228058.001

36. Kuncoro, H., 2015. Does the Credible Fiscal Policy Support the Prices Stabilization? Review of Economic Perspectives, 15(2), pp. 137-156. https://doi: 10.1515/revecp-2015-0014

37. Kydland, F. and Prescott, E., 1977. Rules Rather than Discretion: the Inconsistency of Optimal Plans. Journal of Political Economy, 85(3), pp. 473-492. https://doi: 10.1086/260580

38. Lin, S., and Ye, H., 2009. Does inflation targeting make a difference in developing countries? Journal of Development Economics, 89(1), pp. 118-123. https://doi.org/10.1016/j.jdeveco.2008.04.006

39. López-Enciso, E., Vargas-Herrera, H. and Rodríguez-Niño, N., 2016. La estrategia de inflación objetivo en Colombia. Una visión histórica. Borradores de Economía, No. 952. https://doi.org/10.32468/be.952

40. Mankiw, N., Reis, R. and Wolfers, J., 2003. Disagreement about Inflation Expectations. NBER Working Paper, No. 9796, pp. 1-60. https://doi. org/10.1086/ma.18.3585256

41. Minea, A. and Tapsoba, R., 2014. Does inflation targeting improve fiscal discipline? Journal of International Money and Finance, 40(1), pp. 185-203. https://doi.org/10.1016/j.jimonfin.2013.10.002

42. Mishkin, F. S., 2007. Monetary Policy Strategy. The MIT Press.

43. Mishkin, F. S. and Savastano, M., 2001. Monetary policy strategies for Latin America. Journal of Development Economics, 66(2), pp. 415-444. https://doi. org/10.1016/s0304-3878(01)00169-9

44. Montes, G. and Açar, T., 2018. Fiscal credibility and disagreement in expectations about inflation: evidence for Brazil. Economics Bulletin, 38(2), pp. 826-843.

45. Montes, G. and Souza, I., 2020. Sovereign default risk, debt uncertainty and fiscal credibility: The case of Brazil. The North American Journal of Economics and Finance, 51(C), pp. 1-26. https://doi.org/10.1016/j.najef.2018.09.009

46. Moody's Investors Service, 2014. Moody's upgrades Colombia's rating to Baa2 from Baa3; outlook stable. July. (Rating Action: Colombia).

47. Naert, F., 2011. Credibility of Fiscal Policies and Independent Fiscal Bodies. Review of Business and Economic Literature, 56(3), pp. 288-309. 
48. Roberts, J.M., 1997. Is Inflation Sticky?. Journal of Monetary Economics, 39(2), 173-196. https://doi.org/10.1016/S0304-3932(97)00017-2

49. Sargent, T. and Wallace, N., 1981. Some unpleasant monetarist arithmetic. Federal Reserve Bank of Minneapolis, Quarterly Review, pp. 1-17. https:// doi.org/10.21034/qr.531

50. Shirakawa, M., 2012. The Importance of Fiscal Sustainability: Preconditions for Stability in the Financial System and in Prices. Remarks at the Banque de France Financial Stability Review Launch Event in Washington D.C. April, 1-3.

51. Strohsal, T., Melnick, R. and Nautz. D., 2016. The time-varying degree of inflation expectations anchoring. Journal of Macroeconomics, 48(C), pp. 62-71. https://doi.org/10.1016/j.jmacro.2016.02.002

52. Thornton, J. and Vasilakis, C., 2019. Do fiscal rules reduce government borrowing costs in developing countries? International Journal of Finance and Economics, pp. 1-12. https://doi.org/10.1002/ijfe.1771

53. Woodford, M., 2003. Interest and Prices: Foundations of a Theory of Monetary Policy. Princeton University Press.

54. Wooldridge, J., 2001. Applications of Generalized Method of Moments Estimation. Journal of Economic Perspectives, 15(4), pp. 87-100. https://doi: 10.1257 jep. 15.4 .87

55. Wyplosz, C., 2005. Fiscal discipline in EMU: rules or institutions? National Institute Economic Review, 191, pp. 70-84. 
TABle A1

Sources of data and description of the variables

\begin{tabular}{|c|c|c|}
\hline Variable & Variable description & Data source \\
\hline$E(\pi)$ & $\begin{array}{l}\text { Inflation expectations computed by the } \\
\text { Central Bank of Colombia. Inflation } \\
\text { expectations are } 1 \text { year forward. The } \\
\text { survey is called "Macroeconomic } \\
\text { Projections of Local and Foreign } \\
\text { Analysts". Data in \%. }\end{array}$ & Central Bank of Colombia \\
\hline CRED LOSS & $\begin{array}{l}\text { Credibility. The indicator was constructed } \\
\text { with the difference between the observed } \\
\text { deficit and the expected deficit. }\end{array}$ & Devised by authors \\
\hline$D E F$ & $\begin{array}{l}\text { Fiscal deficit observed by the Central } \\
\text { National Government }(\% \text { GDP) - } \\
\text { Accumulated in the last } 4 \text { quarters. } \\
\text { Data in } \% \text {. }\end{array}$ & Central Bank of Colombia \\
\hline$E(D E F)$ & $\begin{array}{l}\text { Fiscal deficit expectations (\% GDP). } \\
\text { Expectations come from central bank } \\
\text { surveys. The forecasting deficit is the } \\
\text { overall fiscal deficit. The survey is called } \\
\text { "Macroeconomic Projections of Local and } \\
\text { Foreign Analysts". Data in \% }\end{array}$ & Central Bank of Colombia \\
\hline$\pi$ & $\begin{array}{l}\text { Inflation accumulated in } 12 \text { months } \\
\text { measured by the variation of the } \\
\text { consumer price index. Data in } \% \text {. }\end{array}$ & Central Bank of Colombia \\
\hline$e$ & $\begin{array}{l}\text { Exchange rate (month average) of the } \\
\text { Colombian peso/United States dollar. }\end{array}$ & Central Bank of Colombia \\
\hline$y$ & $\begin{array}{l}\text { Gross domestic product. Series was built } \\
\text { on real Colombian currency with constant } \\
\text { prices from } 2005 \text {. The variable is } \\
\text { seasonally adjusted by the central bank. } \\
\text { In the models, the series was used in } \\
\text { natural logarithm. }\end{array}$ & Central Bank of Colombia \\
\hline$U$ & $\begin{array}{l}\text { Unemployment rate with seasonal } \\
\text { adjustment X12. Data in \%. }\end{array}$ & Central Bank of Colombia \\
\hline$V I X$ & $\begin{array}{l}\text { Volatility of the stock market index S\&P } \\
500 .\end{array}$ & Federal Reserve of St. Louis \\
\hline$D$ & $\begin{array}{l}\text { A dummy variable. The dummy takes a } \\
\text { value of } 1 \text { for year } 2008 \text { and } 0 \text { for the rest. }\end{array}$ & Devised by authors \\
\hline
\end{tabular}


TABLE A2

Descriptive statistics

\begin{tabular}{|c|c|c|c|c|}
\hline Variable & Mean & Min. & Max. & SD. \\
\hline$E(\pi)$ & 3.9455 & 2.8766 & 5.6900 & 0.7804 \\
\hline$D E F$ & 3.0272 & 1.2166 & 4.6816 & 0.8691 \\
\hline$E(D E F)$ & 2.4996 & 0.6500 & 4.0800 & 0.9183 \\
\hline CRED LOSS & 0.9798 & 0.0200 & 3.1400 & 0.7920 \\
\hline$\pi$ & 4.3057 & 1.8464 & 8.2436 & 1.6576 \\
\hline$e$ & $2,360.02$ & $1,762.14$ & $3,462.01$ & 495.15 \\
\hline$U$ & 10.6105 & 8.4389 & 14.2076 & 1.3231 \\
\hline$y$ & 12.0552 & 11.7126 & 12.3205 & 0.1811 \\
\hline$V I X$ & 18.1577 & 9.5100 & 44.1400 & 7.7106 \\
\hline
\end{tabular}

Note: $E(\pi), D E F, E(D E F), C R E D$ LOSS, $\pi$ and $U$ were used in $\%$.

\section{TABle A3}

Unit root tests (ADF, PP, and KPSS)

ADF

PP

KPSS

\begin{tabular}{|c|c|c|c|c|c|c|c|c|c|c|c|c|}
\hline Series & Lags & Esp. & Test & $\begin{array}{c}\text { C.V } \\
(1 \%)\end{array}$ & Banda & Esp. & Test & $\begin{array}{c}\text { C.V } \\
(1 \%)\end{array}$ & Banda & Esp. & Test & $\begin{array}{c}\text { C.V } \\
(5 \%)\end{array}$ \\
\hline$E(\pi)$ & 1 & $\mathrm{C}$ & -2.44 & -3.54 & 3 & $\mathrm{~N}$ & -1.28 & -2.60 & 4 & $\mathrm{C}, \mathrm{T}$ & 0.16 & 0.14 \\
\hline $\begin{array}{l}\text { CRED } \\
\text { LOSS }\end{array}$ & 2 & $\mathrm{~N}$ & -1.16 & -2.60 & 1 & $\mathrm{~N}$ & -1.61 & -2.60 & 5 & $\mathrm{C}, \mathrm{T}$ & 0.15 & 0.14 \\
\hline$\pi$ & 1 & $\mathrm{C}$ & -3.15 & -3.56 & 3 & $\mathrm{~N}$ & -1.06 & -2.60 & 3 & $\overline{\mathrm{C}, \mathrm{T}}$ & 0.16 & 0.14 \\
\hline$e$ & 0 & $\mathrm{~N}$ & -0.65 & -2.60 & 1 & $\mathrm{~N}$ & -0.53 & -2.60 & 6 & $\mathrm{C}, \mathrm{T}$ & 0.23 & 0.14 \\
\hline$U$ & 0 & $\bar{C}$ & -2.86 & -3.55 & 3 & $\mathrm{C}$ & -2.86 & -3.55 & 5 & $\bar{C}$ & 0.84 & 0.46 \\
\hline$y$ & 0 & $\mathrm{C}, \mathrm{T}$ & -1.75 & -4.11 & 4 & $\mathrm{C}, \mathrm{T}$ & -1.59 & -4.13 & 6 & $\mathrm{C}$ & 1.00 & 0.46 \\
\hline$V I X$ & 0 & $\mathrm{C}$ & -3.61 & -3.54 & 1 & $\mathrm{C}$ & -3.49 & -3.54 & 5 & $\mathrm{C}, \mathrm{T}$ & 0.15 & 0.14 \\
\hline
\end{tabular}

Note: C.V., critical value. Trend (T) and intercept (I) are included based on Schwarz criterion. ADF - the final choice of lag was made based on Schwarz criterion. PP and KPSS - spectral estimation method is Bartlett kernel and the Newey-West Bandwidth is used.

\section{TABLE A4}

VAR lag order selection criteria (with constant)

\begin{tabular}{|c|c|c|c|}
\hline Lag & Schwarz & Lag & Schwarz \\
\hline Equation (4) & & Equation (5) & \\
\hline 0 & 8.81 & 0 & 14.31 \\
\hline 1 & $1.50 *$ & 1 & $6.74 *$ \\
\hline 2 & 2.08 & 2 & 7.56 \\
\hline Equation (6) & & Equation (7) & \\
\hline 0 & 2.95 & 0 & 19.57 \\
\hline 1 & $-3.75^{*}$ & 1 & $13.45^{*}$ \\
\hline 2 & -3.07 & 2 & 14.70 \\
\hline
\end{tabular}

Note: * denotes the lag order selection. 
TABLE A5

Number of cointegrating relations by model

\begin{tabular}{|c|c|c|c|c|c|}
\hline Data trend: & None & None & Linear & Linear & Quadratic \\
\hline Test type & $\begin{array}{l}\text { No intercept } \\
\text { No trend }\end{array}$ & $\begin{array}{l}\text { Intercept } \\
\text { No Trend }\end{array}$ & $\begin{array}{l}\text { Intercept } \\
\text { No trend }\end{array}$ & $\begin{array}{l}\text { Intercept } \\
\text { trend }\end{array}$ & $\begin{array}{l}\text { Intercept } \\
\text { trend }\end{array}$ \\
\hline $\begin{array}{l}\text { Equation (4) } \\
\text { trace }\end{array}$ & 2 & 3 & 2 & 2 & 3 \\
\hline $\begin{array}{l}\text { Equation (5) } \\
\text { trace }\end{array}$ & 2 & 2 & 2 & 2 & 3 \\
\hline $\begin{array}{l}\text { Equation (6) } \\
\text { trace }\end{array}$ & 1 & 1 & 2 & 2 & 3 \\
\hline $\begin{array}{l}\text { Equation (7) } \\
\text { trace }\end{array}$ & 1 & 1 & 1 & 1 & 2 \\
\hline \multicolumn{6}{|c|}{ Johansen's cointegration test } \\
\hline $\begin{array}{l}\text { Hyp. N. of } \\
\text { CE (s) }\end{array}$ & Eigen value & Trace statistic & \multicolumn{2}{|c|}{ Critical value $(0.05)$} & p-value \\
\hline \multicolumn{6}{|l|}{ Equation (4) } \\
\hline $\mathrm{R}=0$ & 0.50 & 96.73 & \multicolumn{2}{|c|}{69.81} & 0.00 \\
\hline $\mathrm{R} \leq 1 * *$ & 0.46 & 60.18 & \multicolumn{2}{|c|}{47.85} & 0.00 \\
\hline $\mathrm{R}=2$ & 0.31 & 27.34 & \multicolumn{2}{|c|}{29.79} & 0.09 \\
\hline \multicolumn{6}{|l|}{ Equation (5) } \\
\hline $\mathrm{R}=0$ & 0.62 & 116.19 & \multicolumn{2}{|c|}{76.97} & 0.00 \\
\hline $\mathrm{R} \leq 1 * *$ & 0.50 & 65.87 & \multicolumn{2}{|c|}{54.07} & 0.00 \\
\hline $\mathrm{R}=2$ & 0.27 & 29.77 & \multicolumn{2}{|c|}{35.19} & 0.17 \\
\hline \multicolumn{6}{|l|}{ Equation (6) } \\
\hline $\mathrm{R}=0 * *$ & 0.56 & 95.52 & \multicolumn{2}{|c|}{76.97} & 0.00 \\
\hline $\mathrm{R} \leq 1$ & 0.35 & 52.48 & \multicolumn{2}{|c|}{54.07} & 0.06 \\
\hline \multicolumn{6}{|l|}{ Equation (7) } \\
\hline $\mathrm{R}=0 * *$ & 0.62 & 109.60 & \multicolumn{2}{|c|}{88.80} & 0.00 \\
\hline $\mathrm{R} \leq 1$ & 0.42 & 59.65 & \multicolumn{2}{|c|}{63.87} & 0.10 \\
\hline
\end{tabular}

Note: *Model selected by the Schwarz criterion. Values based on Mackinnon. **Denotes the null hypothesis rejection at $5 \%$.

\section{TABLE A6}

List of GMM instruments

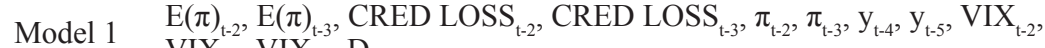
VIX $_{t-3}$, VIX $_{t-4}, D_{t-1}$

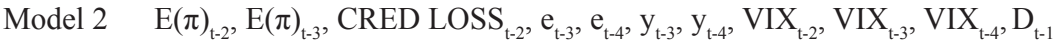

Model $3 \mathrm{E}(\pi)_{\mathrm{t}-2}, \mathrm{E}(\pi)_{\mathrm{t}-3}, \mathrm{E}(\pi)_{\mathrm{t}-4}$, CRED LOSS $\mathrm{L}_{\mathrm{t}-2}, \mathrm{CRED} \mathrm{LOSS}_{\mathrm{t}-3}, \pi_{\mathrm{t}-2}, \pi_{\mathrm{t}-3}, \mathrm{U}_{\mathrm{t}-2}$, VIX $_{t-2}, D_{t-1}$

Model $4 \quad \mathrm{E}(\pi)_{t-2}, \mathrm{E}(\pi)_{t-1}, \mathrm{E}(\pi)_{t-4}, C R E D \operatorname{LOSS}_{t-2}, C R E D \operatorname{LOSS}_{t-3}, e_{t-2}, e_{t-3}, U_{t-2}, U_{t-3}$, $\mathrm{U}_{\mathrm{t}-4}, \mathrm{VIX}_{\mathrm{t}-2}, \mathrm{D}_{\mathrm{t}-1}$

Model $5 \quad \mathrm{E}(\pi)_{t-2}, \mathrm{E}(\pi)_{t-3}$, CRED LOSS $\mathrm{t}-2_{2}$, CRED LOSS $\mathrm{t}_{\mathrm{t}-3}, \mathrm{e}_{\mathrm{t}-2}, \mathrm{e}_{\mathrm{t}-3}, \mathrm{y}_{\mathrm{t}-4}, \mathrm{y}_{\mathrm{t}-5}, \mathrm{U}_{\mathrm{t}-2}, \mathrm{U}_{\mathrm{t}-3}$, $\operatorname{VIX}_{t-2}, \pi_{t-2}, \pi_{t-3}, D_{t-1}$ 